\title{
PREVALENCE OF SMALL RUMINANT LENTIVIRUS INFECTIONS IN SHEEP AND GOATS IN SOME REGIONS OF VOJVODINA PROVINCE
}

\author{
Sara Savić ${ }^{* 1}$, Marina Žekić Stošić ${ }^{1}$, Dejan Bugarski ${ }^{1}$, \\ Doroteja Marčić1, Aleksandar Milovanović́ ${ }^{1}$, Aleksandar Potkonjak ${ }^{2}$ \\ ${ }^{1}$ Scientific Veterinary Institute "Novi Sad", Novi Sad, Republic of Serbia \\ ${ }^{2}$ University of Novi Sad, Faculty of Agriculture, Department \\ for Veterinary Medicine, Novi Sad, Republic of Serbia
}

\section{Abstract}

Small Ruminant Lentivirus causes a chronic lifelong, multisystemic diseases in sheep and goats with or without clinical manifestation. Maedivisna virus (MVV) and Caprine arthritis encephalitis virus (CAEV) are often considered together as small ruminants lentivirus (SRLV) because of their phylogenetic correlation and the interspecies transmission between sheep and goats.

During a five-year period, from 2014 to 2018, a monitoring on male animals (rams and bucks) used for breeding was conducted with the aim to determine antibodies against SRLV using ELISA serological method. In total, serum samples from 5,039 animals were analysed and the overall seroprevalence of $5.59 \%$ was found. The seroprevalence for the whole period was $5.15 \%$ in male animals while in female animals it was $6.15 \%$. During the whole $2014-2018$ period, seroprevalence was $4.52 \%$ in rams, $17.61 \%$ in bucks, $1.14 \%$ in sheep and $12.57 \%$ in goats. Compared to earlier studies and within the study period, the seroprevalence for SRLV actually decreased in rams and bucks. The study results show that annual monitoring program is very important and has to be conducted in the future in order to keep the disease under control. The program helps in raising awareness and familiarizing owners with SRLV and the importance of breeding seronegative animals.

Key words: SRLV, Meadi Visna virus, sheep, goats

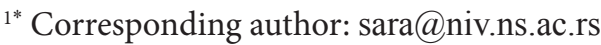




\title{
PREVALENCA INFEKCIJE LENTIVIRUSOM MALIH PREŽIVARA KOD OVACA I KOZA U NEKIM DELOVIMA VOJVODINE
}

\author{
Sara Savićn ${ }^{1}$ Marina Žekić Stošić ${ }^{1}$, Dejan Bugarski ${ }^{1}$, \\ Doroteja Marčić ${ }^{1}$, Aleksandar Milovanović ${ }^{1}$, Aleksandar Potkonjak² \\ ${ }^{1}$ Naučni institut za veterinarstvo "Novi Sad”, Novi Sad, Republika Srbija \\ ${ }^{2}$ Univerzitet Novi Sad, Poljoprivredni fakultet, Departman za \\ veterinarsku medicinu, Novi Sad, Republika Srbija
}

\section{Kratak sadržaj}

Lentivirus malih preživara izaziva dugotrajno, multisistemsko hronično oboljenje kod ovaca i koza koje može biti sa ili bez kliničkih simptoma. Medi-visna virus (MVV) i virus artritisa i encefalitisa koza se smatraju lentivirusima malih preživara (SRLV) zbog njihove filogenetske sličnosti i prenošenja viruse među vrstama.

Tokom perioda od 5 godina, od 2014-2018, sprovođen je godišnji monitoring program za muške priplodne životinje, radi utvrđivanja antitela protiv SRLV virusa pomoću ELISA serološke metode. Ukupno je ispitano 5039 uzoraka krvnih seruma životinja i utvrđena ukupna seroprevalenca od 5.59\%. Kod muških životinja seroprevalenca za ceo period je 5,15\%, a kod ženskih životinja je 6,15\%. Tokom posmatranog perioda utvrđena je seroprevalenca kod ovnova $4.52 \%$, kod jarčeva $17.61 \%$, kod ovaca $1.14 \%$ i kod koza $12.57 \%$. U poređenju sa rezultatima prethodnih studija, a i tokom perioda ovog istraživanja, utvrđeno je da je seroprevalenca za virus SRLV zapravo opala kod ovnova i jarčeva. Iz ovakvih rezultata se može zaključiti da je godišnji monitoring program veoma važan i mora da se održi i u budućnosti, da bi se ovo oboljenje držalo pod kontrolom. Program takođe doprinosi i povećanju svesti kod vlasnika životinja / farmera o SRLV i značaju gajenja seronegativnih životinja.

Ključne reči: SRLV, Medi Visna virus, ovce, koze 


\section{INTRODUCTION}

Maedi-visna virus (MVV) and Caprine arthritis encephalitis virus (CAEV) are often considered together as small ruminants lentivirus (SRLV) because of their phylogenetic correlation and the interspecies transmission between sheep and goats. SRLV belongs to genus Lentivirus, subfamily Orthoretrovirinae and family Retroviridae. SRLV can cause a chronic lifelong, multisystemic diseases in sheep and goats with clinical manifestation in adults. Due to a slow progress of the disease, the possibility of infection within a flock is high. Most of infected animals never develop clinical symptoms. In sheep, name "visna" stands for the disease that affects central nervous system, a neurological form of the disease and predominantly causes meningoencephalitis in sheep. The term "maedi" stands for infection of the lungs. Besides this, the virus can also affect other organs such as udder.

Small ruminant lentiviruses include viruses with diverse genotypes that frequently cross the species barrier between sheep and goats that display a great genetic variability. There are five genotypes (A-E) of SRLV (Minguijón et al., 2015). Genetic variability is a key feature of small ruminant lentivirus genome and is essential for accurate diagnosis. There is a slight variation of the strains of SRLV and specific symptoms can be more dominant depending on the differences in genetic susceptibility patterns. Depending on the cell type, visna/ maedi virus infection may lead to a cytopathic effect, or remain unnoticed.

Caprine arthritis and encephalitis virus (CAEV) can affect joints, central nervous system and udder in goats (Marcom et al., 1991). Arthritis can be found in infected animals which are 1 to 6 years old, with swollen carpal joints, causing limp and weight loss in sick animals (Blacklaws, 2004).

Serological diagnostic methods are considered the most convenient for detection of SRLV infections (de Andres et al. 2005). Different serology methods can be used for diagnostics of the disease, like agar gel immunodiffusion test, indirect immunofluorescence test and ELISA test (Larruskain and Jugo, 2013). After infection, seroconversion takes several weeks, mostly between 2 and 8 (Carrozza et al., 2009; Reina et al., 2011).

Domesticated host animals of the virus are sheep (Ovis aries) and goats (Capra hircus). European mouflon (Ovis aries musimon) is also recognized as a host in the wilderness (Straub, 2004). The earliest reports on the disease come from South Africa and the USA (Straub, 2004, Randall et al. 1988), but nowadays the disease can be found in all the countries where sheep are bred. This virus is distributed all over Europe and in many other countries worldwide. According to International Animal Health organization (OIE), back in 2005, the disease was either reported as present or known to be present in most of 
European countries (Austria, Belgium, Bulgaria, Czech Republic, Denmark, Finland, France, Germany, Hungary, Iceland, Ireland, Luxembourg, Netherlands, Norway, Poland, Portugal, Sweden, Switzerland and UK) (OIE, Handistatus, 2005). One of the most important factors that affected the spreading of this disease in different countries (such as Denmark, Norway, Finland and the United Kingdom) is the trade of animals without control (Gjerset et al 2007). In some other countries there was serological evidence and/or isolation of the agent (Latvia, Slovakia) and in some countries the virus was not found at that time. Later on, the evidence of the disease appeared in those countries too, like in Serbia and Romania (Vidić et al., 2008; Mihai et al., 2018). So far, SRLV-free countries are New Zealand and Australia. The first survey in Serbia was conducted in 2008 , when a prevalence of $16.24 \%$ was found in the whole country by ELISA test (Vidić et al., 2008). The attention was brought to this disease at that time and then in 2012 a seroprevalence of $21 \%$ was found in sheep (varying from $14-30 \%$ in different regions) to $6.81 \%$ in rams (Savić et al., 2012). It is very important to identify the presence of Maedi-visna infection because of the long incubation period, and control of this disease is complicated since there is no treatment, no vaccine and the options for prevention are limited. This is why a monitoring program for breeding animals was introduced in 2016. The purpose of this study was to analyse the seroprevalence in sheep, rams, goats and bucks after the 3 years of active monitoring program in breeding animals for SRLV and to show if and how seroprevalence has changed over the study period.

Different studies have shown that all productivity parameter measures appeared to be reduced in the seropositive groups for both goats and sheep, even though the differences were not statistically significant (Leginagoikoa et al., 2010; Barquero et al., 2013; Junkuszew et al., 2016).

\section{MATERIAL AND METHODS}

\section{Material/sampling and sample distribution}

During a five-year period, from 2014-2018, an annual monitoring on male animals (rams and bucks) used for breeding was conducted. The purpose of this program was determination of antibodies against SRLV with ELISA serological method. This program was proposed and coordinated by the Veterinary Directorate of the Ministry of Agriculture, Forestry and Water Management. The monitoring program is planned and announced every year and it applies to the whole country, including all regions. The analyses in this study were done according to that mandatory annual program introduced by the 
government of Serbia and so they included all male animals (rams and bucks) used for breeding. Besides male animals, female animals were also analysed when there was a suspicion that the disease is present in a flock. The region in which the sampling was performed was South Backa and Srem District - a region which is controlled by the Scientific Veterinary Institute "Novi Sad". This means that during the whole study period, each year the animals from the same regions were analysed. In total, serum samples from 5,039 animals were included in the study. Out of the total, 1,316 samples were from sheep, 2,587 samples were from rams, 994 samples were from goats and 142 samples were from bucks. There were 2,729 samples from male and 2,310 samples from female animals analysed for the presence of antibodies against SRLV.

\section{The ELISA methods}

The kits used were ELISA diagnostic kits of two types. First, the screening diagnostic kit was used in order to identify samples positive for antibodies against SRLV. Positive samples identified with screening ELISA kit (ID Screen MVVCAEV Indirect Screening test, IDvet, France) were then analysed with a conformation ELISA kit (INgezim MAEDI Confirmation, Ingenaza, Spain) in order to obtain the conformation of positive samples. Screening kit is designed to detect antibodies against SRLV in sheep and goat serum samples, based on an indirect ELISA technique using a purified pool of SRLV antigenic peptides. Conformation assay was designed to confirm the positive samples obtained in the screening test by detection of specific antibodies against SRLV through the use of specific peptides of genotypes A and B. The sensitivity and specificity of the kits were 95\%.

\section{RESULTS}

During the five-year period, the results were categorized by year and by animal species and categories into tables and pictures. From the total number of 5,039 analysed animal samples, 282 were positive for SRLV, which is $5.59 \%$ of anlysed animals. The seroprevalence for the whole period was $5.15 \%$ only in male animals, while and in female animals it was $6.15 \%$.

Seroprevalence for SRLV for the whole $2014-2018$ period was $4.52 \%$ in rams, and $17.61 \%$ in bucks. In sheep, seroprevalence for the whole period was $1.14 \%$ and in goats it was $12.57 \%$. The number of positive samples for antibodies against SRLV and seroprevalence in sheep, rams, goats and bucks is shown in Table 1 and Figures 1 and 2. 
Table 1. Number of analysed and positive samples of rams, sheep, goats and bucks for antibodies against SRLV during the 2014-2018 period

\begin{tabular}{|c|c|c|c|c|c|c|c|c|c|c|c|c|c|}
\hline \multirow{2}{*}{\multicolumn{2}{|c|}{$\begin{array}{c}\text { Total } \\
\text { Year sample } \\
\text { No }\end{array}$}} & \multicolumn{3}{|c|}{ Sheep } & \multicolumn{3}{|c|}{ Rams } & \multicolumn{3}{|c|}{ Goats } & \multicolumn{3}{|c|}{ Bucks } \\
\hline & & 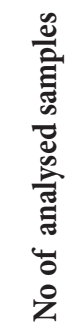 & 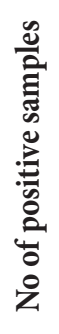 & 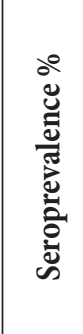 & 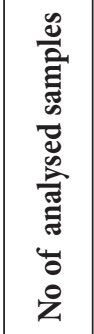 & 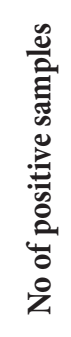 & 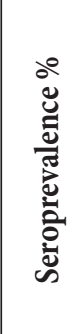 & 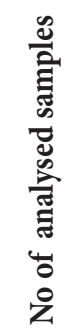 & 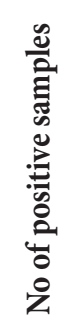 & 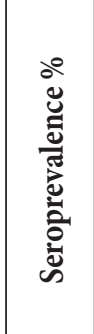 & 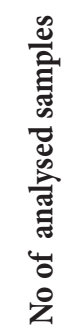 & 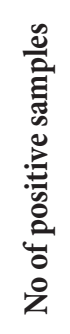 & 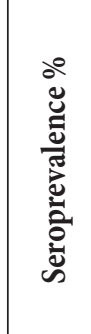 \\
\hline 2014 & 310 & 124 & 0 & - & 19 & 0 & - & 162 & 0 & - & 5 & 0 & - \\
\hline 2015 & 168 & 137 & 2 & 1.46 & 31 & 0 & - & 0 & 0 & - & 0 & 0 & - \\
\hline 2016 & 920 & 351 & 3 & 0.85 & 532 & 53 & 9.96 & 2 & 0 & - & 35 & 8 & 22.86 \\
\hline 2017 & 781 & 258 & 5 & 1.93 & 502 & 18 & 3.58 & 0 & 0 & - & 21 & 10 & 47.62 \\
\hline 2018 & 2860 & 446 & 5 & 1.12 & 1,503 & 46 & 3.06 & 830 & 125 & 15.06 & 81 & 7 & 8.64 \\
\hline Total & 5039 & 1316 & 15 & 1.14 & 2,587 & 117 & 4.52 & 994 & 125 & 12.57 & 142 & 25 & 17.61 \\
\hline
\end{tabular}

\section{Positive samples 2014-2018}

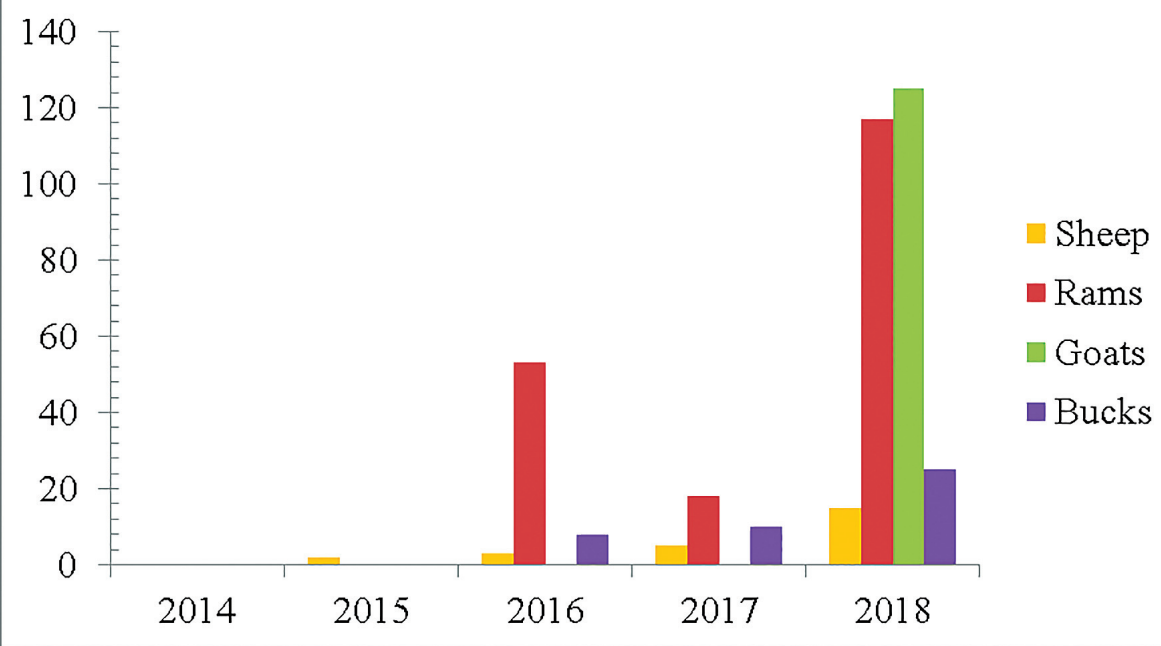

Figure 1. Number of positive samples for antibodies against SRLV virus in sheep, rams, goats and bucks for the 2014-2018 period 
The number of positive animals in the years 2014 and 2015 was 0 and 2 respectively, leading to no seroprevalence and a very low seroprevalence, respectively. This was most probably due to a very low number of total samples taken during those two years, and also due to a low number of samples taken from goats/bucks. The monitoring program was in preparation and the actual numbers were gained during the next three years, over the period from 2016 to 2018. During this period, the seroprevalence did not change much in sheep $(0.85-1.93 \%)$, but in rams it significantly decreased from 9.96 to $3.06 \%$. The seroprevalence in goats was $15.05 \%$ in 2018 , which is rather high compared to other categories, but in the previous years it was not looked into. The seroprevalence in bucks was mostly inconsistent, but it was decreasing significantly from $47.62 \%$ to $8.64 \%$. Seroprevalence in sheep and rams (3.38\%) is significantly lower than in goats and bucks (13.20\%).

The overall seroprevalence for the whole study period (2014-2018) in sheep, rams, goats and bucks is shown in Figure 2.

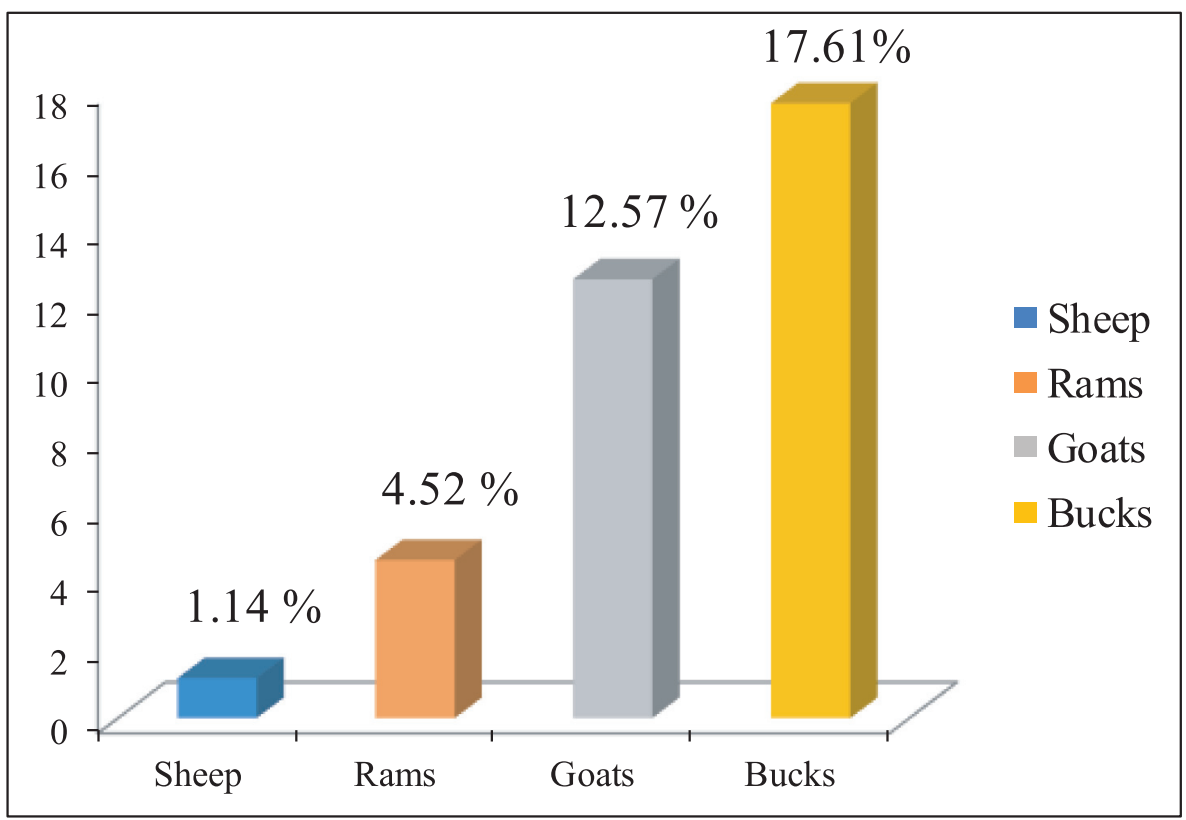

Figure 2. The overall seroprevalence for the whole study period (2014-2018) in sheep, rams, goats and bucks 


\section{DISCUSSION}

During the 2014-2018 period, seroprevalence for SRLV decreased from $9.96 \%$ to $3.06 \%$ in rams and from $47.62 \%$ to $8.64 \%$ in bucks. In sheep, the seroprevalence did not change much over the years $(0.85-1.93 \%)$, but in goats it appeared to be very high during the last year of the study (15.06\%). Compared to previous studies, it can be observed that the overall seroprevalence decreased to $5.59 \%$, and it is very interesting regarding the sex and species categories.

The first survey in Serbia was conducted in 2008 and seroprevalence of $16.24 \%$ was found in the whole country (Vidić et al., 2008). A study from 2012 showed a seroprevalence of $21 \%$ in sheep in Vojvodina region, while in rams it was $6.81 \%$ (Savić et al., 2012). Then, in the period from 2013 to 2015 seroprevalence seemed to be very low, but it was only because a very small number of samples (or even none) were analysed. When the monitoring program coordinated by the Veterinary Directorate started in 2016, a significantly higher number of samples were analysed, but still not from all the categories. Only in 2018, a representative number of samples were gathered from sheep, rams, goats and bucks. What is also important is that seroprevalence in goats and bucks together (13.20\%) was significantly higher than seroprevalence in sheep and rams (3.38\%), even though the number of analysed samples was significantly lower in goats and bucks.

The characteristic of SRLV antibodies is that they are slow in appearance after the infection and this has to be taken into consideration when findings are discussed. Passively obtained antibodies can last for 6 months and when serological examination of sheep is performed before this period, this fact needs to be taken into account as well. Positive serology findings do not mean that symptoms will appear. It means that the animals were in contact with the virus, but the animals will not necessarily be sick. Prevalence can be high in a flock, especially in older animals meaning that there was a contact between the flock and the virus (Gomez-Lucia et al., 2018).

The prevalence of SRLV seems to be much higher in farms where lambs and kids are fed with a pool of colostrum or milk from the tank, a practice that favours transmission to the management system (Leginagoikoa et al., 2010; Barquero et al., 2013). Besides a type of management system (higher SRLV seroprevalence in intensively reared sheep than in semi-intensively and extensively reared sheep), flock size also can be a factor. According to Junkuszew et al. (2016) 70 dams are the limit above which there is an increased risk for lentiviral infection. The route of transmission is related to body fluids, mainly respiratory exudates and milk or colostrum and also airborne, favoured by overcrowding (Barquero et al., 2015). 
The region in the study area is very developed in agriculture with plant production and soil exploitation. Thus, sheep and goats are mostly kept in stables with a lot of animals in a small area. Traditionally, the size of the flock is from one hundred to a few hundred animals. Only in the places where the soil is not suitable enough for plant production, animals can be kept on pastures where they can easily get in contact with other flocks. Also, traditionally, male animals are traded between different flocks. Sheep are most commonly used only for meat production and lambs are not separated from mothers that nurse them, which carries a great risk of getting infected with SRLV through milk or colostrum. There is also a great risk of other ways of infection due to the direct contact with older animals in flock which are all kept together. Goat breeding is oriented exclusively towards milk production and lambs and kids are separated from dams at early stages of life, so it is more appropriate to take measures in order to diminish the risk of infection with SRLV.

The main economic losses resulting from SRLV infection come from the effect of subclinical infection on the productivity of infected flock. The economic impact of this disease is a direct damage from increased mortality in a flock. But besides that, there is a decreased production of animals, a higher level of illness incidence, etc. Seropositive animals have lower level of milk production, shorter lactation period and reduced reproduction abilities. The presence of the disease in a flock significantly affects the value of the animals on the market.

\section{CONCLUSION}

The number of positive animals is a significant finding especially with regards to a longer screening period. It is important to keep the disease under control, because the losses resulting from this disease are significant, which means that the annual monitoring program is crucial. What has not been accomplished so far is including a larger number of goats and bucks in the program in order to gain much more precise results, and to identify the infected flocks.

In the observed region there are seropositive animals within the flock which need to be under control. There is uneven distribution of seropositive animals within the region. However, all the municipalities are affected by SRLV virus.

Annual monitoring program organized by the Veterinary Directorate is an ongoing and continuing program. The obtained results show that this program is very important and needs to be maintained in the future in order to keep the disease under control. The program helps in raising the awareness and 
familiarizing the owners with SRLV and the importance of breeding seronegative animals. A monitoring program that includes more bucks and goats is required in the future as well as a program for seropositive animals. Also, a plan on what to do with them while the seroprevalence in the country is still relatively low is required.

\section{ACKNOWLEDGEMENT}

This paper is part of the research done in the project TR31071 granted by the Serbian Ministry of Education and Science.

\section{Author's contributions:}

Individual contributions of authors to the manuscript, specified by initials in this section are the following: SS made contributions to the concept and design of the study, organisation of work, writing the manuscript and data analysis and prepared the final draft of the manuscript. MŽS completed laboratory analysis of all the samples, drew the maps and worked on technical preparation of the manuscript. DB participated in writing of the manuscript and contributed mostly to data analysis process. DM collected all the epizootical data needed for map drawings and participated in the writing of the manuscript. AM participated in writing of the manuscript and preparation of the final draft of the manuscript, mostly contributing to data analysis. AP participated in writing of the manuscript and preparation of the final draft of the manuscript.

\section{Competing Interests}

All the authors declare that they have no competing interests for the work presented in the Manuscript. The manuscript is not influenced by any personal or financial relationship with people or organizations.

\section{REFERENCES}

1. Barquero N., Domenech A., Gomez-Lucia E. 2015. Infections by Small Ruminant Lentiviruses, LAP Lambert Academic Publishing, Saarbrücken, Germany, ISBN-13: 978-3659744051.

2. Barquero N., Gomez-Lucia E., Arjona A., Toural C., Las Heras A., Fernández-Garayzábal J.F., Ruiz-Santa Quiteria J.A., Doménech A. 2013. Investigation of risk factors associated with infections caused by small ruminant 
lentiviruses. Bulletin of the Veterinary Institute in Pulawy, 57, 4, 473-478. doi: 10.2478/bvip-2013-0082.

3. Blacklaws B.A., Berriatua E. Torsteinsdottir S., Watt N.J., de Andres D., Klein D., Harkiss G.D. 2004. Transmission of small ruminant lentiviruses. Veterinary Microbiology, 101, 3, 199-208. doi:10.1016/j.vetmic.2004.04.006.

4. Carrozza M.L., Mazzei M., Lacerenza D., Del Chiaro L., Giammarioli M., Marini C., Rutili D., Rosati S., Tolari F. 2009. Seroconversion against SU5 derived synthetic peptides in sheep experimentally infected with different SRLV genotypes. Veterinary Microbiology, 369-374, 137, 3-4. doi:10.1016/j.vetmic.2009.01.032.

5. Cutlip R.C., Lehmkuhl H.D., Schmerr M.J., Brogden K.A. 1988. Ovine progressive pneumonia (maedi-visna) in sheep. Veterinary Microbiology, 17, 3, 237-250. doi:10.1016/0378-1135(88)90068-5.

6. de Andres D., Klein D., Watt N.J., Berriatua E., Torsteinsdottir S., Blacklaws B.A., Harkiss G.D. 2005. Diagnostic tests for small ruminant lentiviruses. Veterinary microbiology, 107, 49-62. doi:10.1016/j.vetmic.2005.01.012.

7. Gjerset B., Jonassen C.M., Rimstad E. 2007. Natural transmission and comparative analysis of small ruminant lentiviruses in the Norwegian sheep and goat populations. Virus Research, 125, 2, 153-161. doi:10.1016/j. virusres.2006.12.014.

8. Gomez-Lucia E., Barquero N., Domenech A. 2018. Maedi-Visna virus: current perspectives, Veterinary Medicine (Auckland, N.Z.), 9, 11-21. doi: 10.2147/VMRR.S136705.

9. Junkuszew A., Dudko P., Bojar W., Olech M., Osiński Z., Gruszecki T.M., Kania M.G., Kuźmak J., Czerski G. 2016. Risk factors associated with small ruminant lentivirus infection in eastern Poland sheep flocks. Preventive Veterinary Medicine, 127, 44-49. doi:10.1016/j.prevetmed.2016.03.011.

10. Larruskain A. and Jugo B.M. 2013. Retroviral Infections in Sheep and Goats: Small Ruminant Lentiviruses and Host Interaction. Viruses. 5, 8, $2043-$ 2061. doi:10.3390/v5082043.

11. Leginagoikoa I., Minguijón E., Juste R.A., Barandika J., Amorena B., de Andrés D., Badiola J.J., Luján L., .Berriatua E. 2010. Effects of housing on the incidence of Visna/Maedi virus infection in sheep flocks. Research in Veterinary Science, 88, 3, 415-421. doi:10.1016/j.rvsc.2009.11.006.

12. Marcom K.A., Pearson L.D., Chung C.S., Poulson J.M., Demartini J.C. 1991. Epitope analysis of capsid and matrix proteins of North American ovine lentivirus field isolates. Journal of clinical microbiology, 29, 7, 1472-1479. doi: 10.1128/JCM. 
13. Mihai I., Crivei I.C., Horhogea C., Savuta G., Velescud E. 2018. Preliminary Serological Investigation on Caprine Arthritis and Encephalitis Virus Infection in a Goat Farm from North-Eastern Romanian Region. Bulletin UASVM Veterinary Medicine, 75, 2. doi:10.15835/buasvmcnvm:2017.0061.

14. Minguijón E., Reina R., Pérez M., Polledo L., Villoria M., Ramírez H., Leginagoikoa I., Badiola J.J., García-Marín J.F., de Andrés D., Luján L., Amorena B., Juste R.A. 2015. Small ruminant lentivirus infections and diseases. Veterinary Microbiology, 14, 181, 1-2, 75-89. doi: 10.1016/j.vetmic.2015.08.007.

15. OIE: Handistatus. 2005. Available at: https://www.cabi.org/isc/ datasheet/59452\#59945D22-0E77-4B2E-8B26-03F4A7569A1B.

16. Reina R., Juganaru M.M., Profiti M., Cascio P., Cerutti F., Bertolotti L., De Meneghi D., Amorena B., Rosati S. 2011. Immunological parameters in goats experimentally infected with SRLV genotype E, strain Roccaverano. Veterinary Immunology and Immunopathology, 139, 2-4, 237-244. doi:10.1016/j.vetimm.2010.11.001.

17. Savić S., Vidić B., Bugarski D., Grgić Ž. 2012. Findings of specific antibodies against Maedi-Visna virus in sheep population in the region of Vojvodina. In Conference proceedings, International Conference on BioScience: Biotechnology and Biodiversity - Step in the Future - The Forth Joint UNS - PSU, Institute of Field and Vegetable Crops, Novi Sad, 109-114. ISBN 978-86-80417-40-0.

18. Straub O.C. 2004. Maedi-Visna virus infection in sheep. History and present knowledge. Comparative Immunology, Microbiology and Infectious Diseases, 27, 1, 1-5. doi:10.1016/S0147-9571(02)00078-4.

19. Vidić B., Grgić Ž., Savić-Jevđenić S., Maljković M., Milanov D. 2008. Prevalence of maedi-visna in sheep herds. Arhiv veterinarske medicine, 1, 1, 30-40. ISSN 1820-9955. doi:10.46784/e-avm.vli1.221.

Received: 13.01.2020.

Accepted: 09.05.2020. 